\title{
Chłopskie księgozbiory domowe. Kulturowe uwarunkowania tworzących się zbiorów domowych i pamiątek na terenie gminy Zabłudów od końca XIX wieku
}

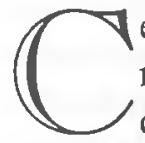
elem niniejszej pracy jest przedstawienie rozwoju i potrzeb czytelniczych w środowisku wiejskim w drugiej połowie XIX wieku, rodzącej się wówczas potrzeby gromadzenia i przechowywania druków i pamiątek. Są to trudne do uchwycenia i opisania procesy budowania tożsamości kulturowej. Zdaję sobie sprawę, iż ograniczenie opisu związanego z założoną problematyką do terytorium gminy Zabłudów, w realiach ówczesnego Imperium Rosyjskiego i polityki zaborcy wobec jakichkolwiek prób budowania świadomości narodowej napotykały na trudności i restrykcje. Wobec wyjątkowego ubóstwa źródeł z terenu objętego opisem - badanie nad odbiorcą chłopskim ówczesnej produkcji, choćby druków ulotnych, jest zadaniem ryzykownym. Ale podjęcie tego ryzyka jest konieczne, ażeby poddać opisowi początki zainteresowań czytelniczych, prób gromadzenia druków i wszelkiego rodzaju dokumentów nazywanych często „domowymi papierami”, będących niczym innym jak zalążkami przyszłych domowych zbiorów bibliotecznych. I choć pojęcie biblioteki wymaga osobnego wyjaśnienia, w przypadku rozważań nad sytuacją rodzin chłopskich, będziemy posługiwać się terminem biblioteka, wszak w potrzebie gromadzenia zawiera się owa, często trudno uchwytna, niekiedy niemożliwa do zwerbalizowania, tęsknota za biblioteką domową. Nawet niewielki księgozbiór pozwalał w środowisku wiejskim, wobec powszechnego analfabetyzmu, zyskać status „człowieka mądrego”. Owe ambicje wyrastają z końca lat siedemdziesiątych XIX wieku, sq̨ w jakiejś mierze wynikiem represji popowstaniowych, jak również problemów uwłaszczeniowych itp. Książka stała się narzędziem wypełniającym lukę informacyjna, wobec wzmożonej akcji rusyfikacyjnej. Odpowiedzią stawała się konieczność organizowania szkolnictwa polskiego, domowego nauczania i najprzeróżniejszych 
form edukacji.

Praca nie wyczerpuje wszystkich zagadnień związanych z tworzeniem się niewielkich zbiorów bibliotecznych w chłopskich domach, nie rości sobie pretensji do ujmowania tegoż zagadnienia w porządku chronologicznym. Z chwilą odzyskania niepodległości - stan oświaty, również wiejskiej, wymagał natychmiastowych działań. Tworzenie domowych zbiorów ulegał wówczas radykalnej zmianie poprzez powoływanie najprzeróżniejszych ośrodków propagujących oświatę i kulturę, poprzez szkolnictwo i dostęp do książek i polskich czasopism. Nie ujmuję w pracy zniszczeń wojennych ani innych nawałnic dziejowych, które hamowały edukacyjne procesy. Nie ma też w niniejszej próbie opisania procesów i rodzących się potrzeb posiadania własnego księgozbioru a wynikających z określonej polityki budowania „świadomości obywatelskiej” w warunkach PRL-u. Procesy te wymagają wnikliwej analizy źródeł, jak też roli masowo powstających u schyłku lat czterdziestych bibliotek publicznych, ich zasobów i indoktrynacji politycznej. Obawiając się uproszczen, które wynikałyby ze zbyt powierzchownego oglądu tych procesów i przedwczesnych wniosków, pozostawiam ten problem do dalszych, rzetelnych badań. Stąd w niniejszej pracy, pojawić się może pewien niedosyt, że wiele problemów nie jest nawet zasygnalizowanych a materiał poddany wstępnemu opisowi jest przypadkowy. Na usprawiedliwienie niechaj pozostanie przekonanie, wynikające $\mathrm{z}$ analizy przeprowadzonej w kilkunastu miejscach poddanego opisowi obszaru, że informacje zdobyte od posiadaczy księgozbiorów domowych, wobec niemożliwości zdobycia jakichkolwiek źródeł pisanych, stają się jedynymi źródłowymi materiałami. W przypadku wyznawców prawosławia sygnalizuję jedynie problemy niepolskich grup narodowościowych, które podlegały innym procesom i dla których okres zniewolenia rosyjskiego był czasem podkreślanym po dzień dzisiejszy, sentymentów. Więcej uwagi poświęcam ciagłości potrzeb w przyswajaniu i konsumowaniu tzw. piśmiennictwa ludowego, które pomimo procesów edukacyjnych, wciąż pozostaje do dnia dzisiejszego w dziewiętnastowiecznym kształcie, bez owych wielokrotnie podkreślanych przez badaczy, przemian zmierzających do pozyskania świadomości przyjmowania literatury wysokiej. Estetyka proponowana przez druki z końca dziewiętnastego wieku, rozwijająca się niezmiernie bujnie w dwudziestoleciu międzywojennym; po przerwie „edukacyjnej” wspartej cenzorskimi zapisami peerelowskiej rzeczywistości, od końca lat osiemdziesiątych dwudziestego wieku ,nadrabia zaległości i święci ponownie swoje triumfy. Domowe zasoby biblioteczne wzbogacane są publikacjami propo- 
nowanymi poprzez parafialną sieć kolportażu. Nie podejmuje próby oceny tegoż zjawiska, sygnalizuję jedynie problem. Nie roszczę również sobie pretensji do prognozowania procesów, które w nieodległej przyszłości mogą zmienić dotychczasowy stan rzeczy. Pozostają pytania, których w tej pracy pojawia się może zbyt wiele, ale po to tylko, ażeby uniknąć przedwczesnych i pochopnych wniosków. Pomijam też procesy rodzących się w ostatnich latach na wsi snobizmów związanych z posiadanym i wzbogacanym księgozbiorem.

Nieliczne źródła, którymi się posługiwałem, wymagałyby szczegółowego opisu, poddane zostały jedynie koniecznej weryfikacji, gwoli zilustrowania problemu, zostały włączone do tejże pracy. Kartoteka zapisów dokonanych w ramach działania Towarzystwa Przyjaciół Ziemi Zabłudowskiej, pozostaje w zbiorach autora. Obejmuje ona szersze zagadnienia, które wymagały ocalenia a w przypadku tejże pracy zostały jedynie wykorzystane fragmenty. Wiąże się to nie tylko $\mathrm{z}$ archiwum zapisów wypowiedzi informatorów. Wykorzystano również archiwum fotograficzne i komentarze do fotografii, które dotykały w wielu przypadkach interesującego nas tematu.

Serdeczne podziękowania składam Pani prof. dr. hab. Annie Sitarskiej, bez pomocy której praca nie powstałaby, dziękuję za cenne uwagi i „utulenie tematu".

Badania nad powstawaniem domowych bibliotek należajak pisze Karol Głombiowski „do dziedziny badań z zakresu uczestnictwa w kulturze. (...) Na uczestnictwo w kulturze składają się dwa zasadnicze rodzaje działania: z jednej strony tworzenie i formułowanie przekazów symbolicznych, z drugiej ich odbiór i interpretacja. Między jednym a drugim ogniwem procesu rozwija się skomplikowany ciagg działań, w którym uczestniczą twórcy i odbiorcy przekazów i narzędzia ich utrwalania i rozpowszechniania". ${ }^{\prime}$ Do przytoczonej definicji należałoby dopisać warunki uczestnictwa w kulturze, a mianowicie stosunki społeczne, które wywierają swoje piętno na kontaktach międzyludzkich i prywatny charakter tworzących się księgozbiorów prowadzący do wymiany sąsiedzkiej posiadanych książek, udostępniania ich treści również poprzez oralną formę przekazu i wymianę informacji. Proces komunikacji jest ograniczony społecznie i kulturowo, wszak w środowiskach zamkniętych a do takich należy środowisko chłopskie - obowiązywało określone zapotrzebowanie estetyczne i etyczne (religijne) kształtujące literaturę i jej odbiorców. Zbiorowość realizowała takie cele jak zabezpieczenie i rozwijanie wiedzy, pojęć moralnych i wartości es- 
tetycznych, uznanych przez tą zbiorowość w danym okresie czasu za niezbędne w jej egzystencji. Pojęcia socjologiczne w jakiejś mierze wyznaczają pole badawcze w księgoznawstwie i podejmowanym temacie.

Maria Kocójowa w artykule „W poszukiwaniu modelu badań” - pojęcie środowiska, tak ważnego dla badań bibliologicznych określa jako „ogół czynników: rzeczy, ludzi, instytucji i innych powstałych w toku społecznego współżycia i rozwoju historycznego społeczeństwa, składających się na społeczne otoczenie człowieka". Za odpowiednik definicyjnego określenia „rzeczy” należy przyjąć szerokie pojęcie książki wytworzonej lub znajdującej się w obiegu w będącym obiektem badań ośrodku książki polskiej oraz inne przedmioty materialne warunkujące działalność bibliologiczną. (...) Lakoniczne sformułowanie: „ludzie” pozwala na rozwinięcie pogłębionej interpretacji komunikacyjnej. (...) Badaczy dawnych ośrodków książki polskiej będą interesować przede wszystkim instytucje książki, czyli wydawnictwa, drukarnie, księgarnie, biblioteki, muzea (...) Końcowa fraza encyklopedycznej definicji środowiska społecznego głosi potrzebę rozpatrywania „rzeczy”, „ludzi” i „,instytucji” jako ,powstałych w toku społecznego współżycia i rozwoju historycznego społeczeństwa, składających się na społeczne otoczenie człowieka". Sformułowanie to można uznać za zapowiedź poszukiwania sensu badań ośrodków książki polskiej w konfrontacji z całokształtem procesu dziejowego komunikacji społecznej". ${ }^{2}$ Wiele ciekawych spostrzeżeń przynoszą badania Kazimiery Maleczyńskiej dotyczące jednego aspektu z przytoczonej powyżej definicji a mianowicie produkcji wydawniczej. Z badań tych wynika, że w końcu dziewiętnastego wieku wyraźnie daje się zauważyć wzrost produkcji drukarskiej tekstów literackich, choć piśmiennictwo historyczne ulega gwałtownemu zahamowaniu a interesująca nas literatura ludowa stanowi nieznaczny procent ówczesnych propozycji wydawniczych. ${ }^{3}$ Dane te zapewne sązaniżone, wszak wiele druków ulotnych nie znalazło się w spisach Estreichera i uchwycenie tegoż działu piśmiennictwa jest zadaniem niezmiernie trudnym. Wysoki procent wciąż daje o sobie znać literatura religijna, w tym druki dewocyjne, które najbardziej sąreprezentatywne we wspomnieniach dotyczących chłopskich bibliotek domowych. W pierwszym dziesięcioleciu, pomimo ukazu tolerancyjnego, spada gwaltownie procentowy udział tego typu literatury. Zestawienia procentowe nie wyjaśniają nam udziału literatury przez nas obserwowanej w życiu wsi polskiej. Jeżeli chodzi o literaturę religijna, odnotowywane były książki kierowane do ówczesnej inteligencji, zaś druki przez nas odnotowywane często nie mieściły się w tej kategorii, pomimo tematu sugerującego ich cha- 
rakter religijny. Wydaje się, że udział tego typu wydawnictw był znaczny, nie opatrzonych cenzorskimi zezwoleniami, w kształtowaniu rynku wydawniczego końca dziewiętnastego stulecia.

Szczególnie interesujące wydają się być wnioski Mariana J. Lecha analizującego ludowe biblioteki i czytelnie w Królestwie Polskim. Nie brak w tej rozprawie ważnych stwierdzeń dotyczących ówczesnej polityki wydawniczej w języku polskim inspirowanej przez zaborcę. ${ }^{4}$ Dopiero rok 1905 otwiera możliwości do legalnego działania bibliotek i czytelń ludowych. Niestety, nie udało nam się odnaleźć jakiejkolwiek informacji o działaniu tego typu instytucji w gminie Zabłudów. Istniały w guberni grodzieńskiej, i trzeba przyznać, iż miały one swój wpływ i odegrały znaczną rolę w przenikaniu książki polskiej do chłopskiej chaty. Uzupełniały obieg tej literatury pracowicie rozpowszechnianej przez wszelkiego rodzaju księgonoszy i jarmarcznych handlarzy. Najważniejsze wydają się być „poszerzone obszary wolności”, które pozwalały na swobodniejszy obieg literatury. Nie wpływały one rzecz jasna na poziom proponowanej literatury. Decydowały tu względy estetyczne niewyrobionego, często z trudem wyrwanego z objęć analfabetyzmu, czytelnika. Wiele lat upłynie, zanim edukacja szkolna zmieni ten stan rzeczy, choć pozostanie nadal tęsknota do ,niesamowitych opowieści" docierających zza szczelnie zamkniętych horyzontów. Element sensacyjności ,wielkiego świata" pozostanie nadal w estetyce odbiorcy, żądnego wzruszeń i zadziwień.

Przytoczona powyżej definicja Marii Kocójowej nie zostanie w pełni rozpisana w moich uwagach nad zalążkami tworzonych chłopskich bibliotek domowych. Uzupełni tylko nieznacznie, poprzez materię wspomnień i nielicznych źródeł pisanych na ten wielce ciekawy problem. Biblioteki chłopskie wciąż przeżywają swój dramat. Być może wynika on ze stosunku tego środowiska do książki i czytelników. „Mawiano <książka nie kar$\mathrm{mi}>$, <kto czyta, chce panem być> (...). Jan Wantuła próbował wythumaczyć wyraźną niechęć niektórych środowisk do książki i w roku 1907 pisał: „(...) dziś starsi ludzie, a nawet wielu młodszych ma zupełnie fałszywe pojęcie o wartości książek świeckich i wogóle zapoznaje korzyści czytania. Na wszystkie książki zapatrują się jak na „Bruncliki”, „Meluzyny”, fantastyczne, mało prawdopodobne opowieści, których czytanie nie tylko nie przynosi żadnych korzyści, ale w dodatku człowiek może z nich czytania „Zgłupnąć”. Ta opinia w jakimś stopniu jest aktualna po dzień dzisiejszy.

Przyjrzyjmy się bliżej literaturze, która trafiała „pod strzechy”. 
Książka do nabożeństwa - tak nazywano zbiór modlitw do codziennego odmawiania oraz ,nabożeństwa na wszystkie dni tygodnia” $\mathrm{z}$ dołączeniem „zbioru najużywańszych pieśni”. Modlitewniki zazwyczaj poprzedzał kalendarz w XIX wieku, z rozróżnieniem na kalendarz gregoriański i juliański z wykazem świąt ruchomych i uwagami typu: „Wesela małżeńskiego Kościół św. zakazuje od pierwszej niedzieli adwentowej do Trzech Królów; od środy popielcowej do poniedziałku przewodniego" czy też informacjami: „Rok ma miesięcy dwanaście, tygodni pięćdziesiąt dwa i jeden dzień; dni zaś trzysta sześćdziesiąt pięć i niemal sześć godzin; gdyż słońce przez tyleż dni obiega koło zodyaka. Po czterech zaś latach przybywa dzień jeden, ponieważ cztery razy 6 czyni godzin 24, zaczem rok wtedy bywa przybyszowy". ${ }^{6}$ Książek do nabożeństwa znamy wiele, funkcjonują pod najprzeróżniejszymi tytułami. Decydowała tu, jak przy innym „tworze”, reklamowa otoczka rozpoczynająca swoją rolę od doboru chwytliwego a zarazem pełnego powagi i dostojeństwa tytułu. „Arka pociechy..., Okaż nam oblicze swoje... etc. „ścigała się” w drugiej połowie XIX stulecia z tanimi drukami straganowymi, które zabiegały o coraz szerszy rynek zbytu. Popyt na literaturę straganową wzrastał w miarę rozwoju oświaty i czytelnictwa wśród ludu. Uzupełniał w jakiejś mierze treści podawane w książkach do nabożeństwa, stając się dekalogiem rozpisanym na zdarzenia nurzane w krwistym sosie ludzkich niegodziwości. W ksiazżkach do nabożeństwa istnieje wyraźny zakaz dowolności budowania zbiorów opowieści i modlitw, stąd opatrywano druki kościelne zezwoleniami „cenzorów dzieł treści religijnych" lub aprobatą władz duchownych. Książki do nabożeństwa były w wielu wypadkach elementarzem, na nich uczono sztuki czytania. Wielu moich informatorów podawało, iż alfabetu uczono ich podczas zimowych wieczorów, korzystając z książki do nabożeństwa. „To było takie ważne, kiedy moja mama Katarzyna prowadziła mój palec po kartkach książki do nabożeństwa. Uczyłam się na pamięć litanii, modlitw najprzeróżniejszych a później już śpiewałam razem godzinki i inne pieśni nabożne. Mama żartowała, że będę czytać śpiewająco - to znaczy dobrze. I chyba tak było, bo kiedy już byłam w szkole, a skończyłam cztery oddziały, kłopotów z czytaniem już nie było. A były w naszym domu książki takie jak: Biblia, dwie książki do nabożeństwa z przeznaczeniem dla mężczyzn i kobiet, była też wspólna, z której najczęściej korzystaliśmy. Były też kantyczki ale z nich tylko śpiewaliśmy w okresie Bożego Narodzenia i w karnawale. Choć to był okres krótki, one były najbardziej „wyśpiewane”. I była też książka o świętej Genowefie, moja mama czytała ją wszystkim, 
którzy zbierali się na naszej chacie czy to przy przędzeniu lnu, czy też kiedy kobiety przychodziły niszczyć fasolę, czy po prostu po to, źeby pogadać - wtedy kiedy już omówiono wszystkie tematy, wyśmiano się i wypłakano, wtedy mama sięgała po tę książkę i czytała. Zawsze wydawało mi się, że czytanie trwa zbyt krótko. I choć znałam na pamięć zdarzenia z tej książki, nigdy nie miałam ich dosyć. Święta Genowefa, wygnana i upokorzona, odniosła w końcu zwycięstwo. To był chyba najlepszy przykład dla przetrwania wszelkich przeciwności losu".?

Pamiętam $\mathrm{z}$ własnego dzieciństwa scenę, kiedy przemierzałem wiele kilometrów aby dotrzeć do Józefowa - tam zaraz za dworem mieszkali Ostaszewscy. Pożyczyłem chyba największy ich skarb: „Żywoty Świętych Pańskich" Piotra Skargi. Owinięte w duże chusty dzieło, sfatygowane wypożyczeniami przynosiłem do domu aby poznać męczeńską chwałę wyznawców Chrystusa. To martyrologium było chyba tak ważne, że aby zbudować swoją bibliotekę jako zakładzinę, szukałem tegoż dzieła. Odnalazłem je w antykwariacie i zakupiłem dzieła ks. Skargi i Ojca Prokopa. Po dzień dzisiejszy odczuwam wielki sentyment do tych ksiag i chyba przez to nie wyblakło we mnie po dzień dzisiejszy moje dziecięce zauroczenie.

W drugiej połowie XIX wieku daje się zauważyć niezwykle bujnie rozwijający się rynek piśmiennictwa straganowego, najbardziej nasycającego wieś tanimi książkami i drukami. ${ }^{8}$ Rozchodziły się one bardzo szeroko, docierały na Podlasie razem z kompaniami powracającymi z odległego często pielgrzymiego szlaku, może docierały do bliższych geograficznie miejsc kultowych, przynoszone przez księgonoszy i kupców. Można je było również nabywać w księgarenkach małomiasteczkowych. Nie były one szczególnie w sferze zainteresowań carskich urzędników, jeżeli nie dotykały spraw narodowych. Ale druki jarmarczne oprócz tematyki religijnej zanurzały się coraz bardziej w sensacyjności. Pękały już tradycyjne horyzonty wiejskie, wnikała w nie produkcja wydawnicza, oświata ludu stawała się zadaniem koniecznym. Pozytywistyczne hasło „praca u podstaw" wydawała już pierwsze owoce. Tradycja przekazu oralnego ulegała kodyfikacji wykorzystującej estetykę ludności wiejskiej, zamkniętego chłopskiego kręgu czytelniczego. Cel literatury dla ludu był instrumentalny: oświatowo-propagandowy, co sprawiało, że w jej zakresie znalazły się zarówno wydawnictwa edukacyjne, jak beletrystyczne. „Adresując swe publikacje do czytelnika mało wyrobionego lub wręcz uczącego się czytać, twórcy literatury dla ludu mniej czy bardziej świadomie kroczyli śladami piśmiennictwa dla dzieci i młodzieży, stawiając częstokroć nieuczonego wieśniaka i dziec- 
ko na tym samym poziomie rozwoju umysłowego (...). Zakres pojęcia „literatury dla ludu" komplikuje się dodatkowo, gdy weźmiemy pod uwagę fakt, że w krag czytelnictwa wiejskiego włączono równocześnie tzw. prasę ludową oraz wydawnictwa jarmarczne i dewocyjne, których poczytność była o wiele większa aniżeli wyspecjalizowanych publikacji „dla ludu”. ${ }^{9}$

Jak pisał Ludwik Brożek o wydawcach książek ludowych „Wydawanie tego rodzaju książek opłacało się, wydawców więc książek dla ludu było w wieku XIX wielu. Nie sposób tu oczywiście wymienić wszystkich, przykładowo jednak podać można takich, jak Chociszewski w Poznaniu, Feitzinger w Cieszynie, Fiałek w Chełmie, Foltyn w Wadowicach, Grajnert w Warszawie, Günther w Lesznie, Heneczek w Piekarach, Jeleń w Tarnowie, Kubaczka w Białej, Nowacki w Bochni, Poturalski w Podgórzu, Baabe w Raciborzu, Prószyński (Promyk) w Warszawie i inni. Niektórzy z nich, jak Chociszewski, Fiałek, Prószyński i Sjerp-Polaczek, zasłużyli się w dziejach oświaty, przeważnie jednak „książki dla ludu wydawano, bo przynosiło to niezgorszy dochód. Wśród polskich wydawców książek ludowych nierzadko spotyka się Niemców i Żydów, jak ośmieszony w „Szkicach węglem" warszawski Breslauer, którego następcy, antykwariusze na Świętokrzyskiej wydawali liche książczyny aż do roku 1939 ". ${ }^{10} \mathrm{~W}$ chłopskich chatach gminy Zabłudów pojawiać się poczęły senniki, sybille, karty do flirtowania. Coraz większy począł pojawiać się rozziew pomiędzy literaturą kanoniczną religijna, a źle zrozumianym religijnie dewocyjnym, pełnym sensacji, drukiem, często nieopatrznie występującym przeciwko ,prawdom wiary”. Eliminacja druków ulotnych, traktowanych jako grzeszne, szczególnie tam, gdzie autorzy rozpisywali się z lubością o gwałtach, mordach i czynach lubieżnych - zazwyczaj potępiano, ale akcje kościelne nie zawsze odnosiły zamierzony skutek. Teksty proroctw zapewne pozostawały poza wszelkimi prawami. „Dowodów” na postawioną tezę jest wiele w chłopskich biblioteczkach w gminie Zabłudów.

Rekonstruowanie obrazu funkcjonowania chłopskich bibliotek domowych a właściwie ich zalążków, jest zadaniem prawie niewykonalnym. Pozostawiam jednak odrobinę nadziei, że z niewielkich ułomków źródeł uda się zarysować obraz, pozbawiony koloryzowania a towarzyszący tzw. życiu kulturalnemu dziewiętnastowiecznej, rozdartej zaborami Polski. Mojemu opisowi poddany został maleńki wycinek zabłudowskiej ziemi. Wszelkie trakty prowadziły do Grodna - miasta gubernialnego, w którym rozstrzygane były sprawy sądowe, spadkowe a nieodległy Białystok pełnił funkcję miasta powiatowego. Zbadanie wpływów tychże ośrodków wiejskich, 
ich produkcja wydawnicza „dla ludu”, kolportaż itp. udzieliłyby odpowiedzi na wiele postawionych pytań.

Na podstawie traktatu tylżyckiego z roku 1807 powstał obwód białostoc$\mathrm{ki}$, na prawach guberni, został włączony do cesarstwa rosyjskiego, a w rok później podzielony na cztery powiaty: białostocki, bielski, sokólski i drohiczyński. Ośrodkiem administracyjnym zostaje wyznaczony Białystok, zaś władzę sprawować będzie od tej pory gubernator, który podlegał wraz z zarządzanym terenem wileńskim generałowi-gubernatorowi. Następowała stopniowa rusyfikacja, najpierw administracji regionu a potem podległych jej jednostek. Szczególne nasilenie akcji rusyfikacyjnej daje się zauważyć w latach dwudziestych i trzydziestych XIX wieku. W 1840 roku ukazem carskim podporządkowano Białostocczyznę carskiemu prawodawstwu, likwidując w 1843 roku odrębną jednostkę administracyjną. Inkorporacja ta podyktowana była nie tylko względami administracyjnymi, co politycznymi. Łatwiejszy był w nowym układzie administracyjnym proces rusyfikacji. W granicach obwodu białostockiego znalazł się Zabłudów.

W drugiej połowie XIX wieku Zabłudów otrzymał baron Krunzensztern, senator i dyrektor Komisji Spraw Wewnętrznych. Była to własność donacyjna. „Dobra zabłudowskie należące do barona zmniejszyły się o 25.025 ha w porównaniu z obszarem, jaki posiadała hrabina Demblińska i wynosił 10.360 ha. Gmina Zabłudów według danych z 1895 roku obejmowała 10 okręgów wiejskich (starostw), 45 miejscowości mających 977 domów, 7.158 mieszkańców, uwłaszczonych gospodarstw było 2.843 . W obrębie gminy znajdowały się 23.300 ha gruntów należących do kilku obszarników oprócz barona Krunzenszterna oraz 326 ha ziemi cerkiewnej i kościelnej. Cały obszar gminy z miastem liczył 42.050 ha i miał 11.111 mieszkańców. ${ }^{11}$

Informacje historyczne określające w przybliżeniu teren moich dociekań, pokrywają się ze współczesnym pojęciem gminy Zabłudów. Wymiennie jednak stosować będę nazwę - Ziemia Zabłudowska, choć to określenie nie ma historycznego uzasadnienia a jedynie administracyjny charakter.

Zjawiskiem masowym wśród mieszkańców miasta i okolic był powszechny analfabetyzm, wynikający z ogólnego stanu oświaty. W latach 1843-1857 w powiecie białostockim było zaledwie 5 szkół elementarnych z 87 uczniami, ${ }^{12}$ zaś szkoła zabłudowska liczyła 12 uczniów. Do końca XIX wieku oprócz szkoły elementarnej, funkcjonowała na tym terenie szkoła żydowska (Żydzi w Zabłudowie stanowili około 70\% mieszkańców). 
W 1864 r. całkowicie zlikwidowano nauczanie w języku polskim. Parafia katolicka zobowiązana była do wygłaszania kazań, prowadzenia ksiąg metrykalnych i nauczania religii w języku rosyjskim. Do nabożeństw w kościele katolickim wprowadzono siłą język starocerkiewnosłowiański.

Gmina Zabłudów aktualnie należy do największych pod względem powierzchni w województwie podlaskim. Ludność wywodzi się z osadnictwa mazowieckiego i ruskiego, stąd znaczne jej zróżnicowanie pod względem wyznaniowym i chciałoby się rzec - narodowościowym, ale sprawa ta wymagałaby dodatkowych wyjaśnień, ze względu na istnienie ludności prawosławnej, której świadomość narodowa określana przez nich samych do niedawna jako „tutejsi, prawosławni Polacy”, którzy po unii brzeskiej w większości byli wyznania greckokatolickiego (we wsi Ryboły istniał np. dekanat tejże cerkwi), w ostatnich latach procesy prowadzące do odzyskania tej ludności na rzecz białoruskości i ukraińskości są bardzo silne i nie przebierając w środkach, prowadzące niekiedy do otwartych konfliktów. To również ma wpływ na formowanie się bibliotek domowych ludności prawosławnej.

Dane dotyczące ludności (stan z grudnia 1999 r.): Zabłudów liczy ok. 2.220 mieszkańców a ludność całej gminy wraz z miastem Zabłudów i osadą Dojlidy Górne - około 11.700 osób, w większości są to rolnicy albo emeryci rolni, którzy stanowią ponad 70\% mieszkańców tejże gminy, o powierzchni $348 \mathrm{~km}^{2} .{ }^{13}$

Na terenie gminy funkcjonują trzy parafie prawosławne: (w Zabłudowie, Dojlidach i Rybołach oraz dwie parafie katolickie: w Dojlidach, w skład której wchodzą oprócz Dojlid Górnych, wsie z terenu gminy: Halickie i Kuriany oraz parafia w Zabłudowie, która w pełni obejmuje swoją opieką duszpasterską pozostałe wsie gminy, z wyjątkiem wsi Kudrycze należącej do parafii Juchnowiec Kościelny oraz wsi Rzepniki przypisanej do parafii w Tryczówce. Wymieniam podział administracji kościelnej, wszak ma ona niebagatelny wpływ na kształtowanie się potrzeb czytelniczych swoich parafian, a co za tym idzie również na profil domowych biblioteczek.

\section{Słów kilka o ,potrzebie gromadzenia"}

Oba terminy wymagają wyjaśnień, ale ograniczymy te próby definiowania do stwierdzenia, że trzonem ,potrzeb" czyli chęci posiadania poszukiwanego egzemplarza jest jego „niecodzienność” czyli mówiąc inaczej wyjątkowość. Chłopskim księgozbiorom była przypisana tęsknota do posiadania książek, które posiadały aurę niecodzienności. Nie wynikała ona z faktu, że egzem- 
plarz poszukiwany był rzadki czy trudno dostępny, jego wyjątkowość zasadzała się na otoczce, która towarzyszyła osobom posiadającym ów egzemplarz, nadający im charakter ,nadprzyrodzony”. A chodzi w tym przypadku o właściciela tzw. ksiagg sybilliańskich czy złotych listów. Posiadacza literatury profetycznej traktowano jako osobę obdarzoną charyzma właściwego odczytywania i propagowania treści „wyczytanych”. Przepowiednie dotyczące rychłego nadejścia końca świata i znaki poprzedzające dni ostateczne, zazwyczaj kolportowane były przez osoby posiadające nieskazitelny autorytet w środowisku, nie zważając na osoby sprzedające tego typu literaturę tzw. księgonoszy czy jarmarcznych sprzedawców, którzy pod sakralną otoczką miejsca kultowego czy odbywającego się odpustu, dokonywali transakcji handlowych nie desakralizując w tym przypadku literatury, choć otoczka kolportowania pozostawiała wiele do życzenia. „Sybillę kupił jego ojciec, jeździł aż do Wilna, nikomu nie pożyczał, a kiedy czytał - kładł księgę na poduszkę i tak po czytaniu odnosił ją do kufra. Nazywał ją księgą, choć nie była to wielkich rozmiarów książka. Najczęściej opowiadał o tym co w tej księdze zapisano. Zapamiętałam, że była tam mowa o znakach poprzedzających koniec świata. Tych znaków miało być dwanaście. I że królowa Sybilla rozmawiała o tym z królem Salomonem". ${ }^{14}$

Wielokrotnie odnotowywałem potrzebę posiadania przez moich rozmówców w domowym księgozbiorze tej książki. Była ona wyżej ceniona od literatury „praktycznej”, tj. śpiewników, książek do nabożeństwa, modlitewników, senników. Księga sybillańska, a pod nią się kryły wszelkiego rodzaju druki prognostyczne, przepowiednie a nawet horoskopy. Szczególnie w XIX wieku daje się zauważyć wiele publikacji, które zapewne dla celów handlowych, zaopatrywano w tytuł: „Sybilla polska” (znane są tego typu druki wydawane przez Józefa Chociszewskiego, wielce zasłużonego nie tylko dla Wielkopolski wydawcy i pisarza), a wspomniana wyżej księga jest zapewne wielce popularnym i wielokrotnie wznawianym drukiem „Mądra rozmowa Królowej ze Sabby z królem Salomonem około roku 875 przed narodzeniem Chrystusa Pana". ${ }^{15}$

Wiele z książek, które były zaczątkiem domowych, chłopskich bibliotek - nie zachowało się do naszych czasów. Zawieruchy wojenne najczęściej niszczyły zalążki domowych księgozbiorów. Jak znaczne musiało być ich oddziaływanie, skoro pamięć przechowała fragmenty tamtych ksiag po dzień dzisiejszy, zważywszy, że dzisiejszy rynek pełen jest tego typu sensacyjnej literatury. „Książki były pod kluczem w kufrze. Wydobywano je podczas wielkich świąt" (powszechne). Na moje pytanie co się kryje 
pod tym terminem, informatorzy odpowiadali, iż „był to najczęściej czas Bożego Narodzenia i tak zwanych świętych dni, które ciągnęły się aż do Trzech Króli. Albo razem z Biblią kładziono na tramie (trama-belka podwieszająca sufit a biegnąca przez długość chaty - przyp. J.L.) Na tramie przechowywano również cukier chowając go przed dziećmi. I nie wiem czy z większym pożądaniem patrzyliśmy na grzbiety ciemnych, skórzanych opraw książek czy na naczynie z cukrem. Do dzisiaj śni mi się tamta izba i czując słodycz w ustach przewracam karty tamtej księgi, nam dzieciom, pokazywanej okazjonalnie". ${ }^{16}$

Książki dzieliły los domu, wraz z świętymi obrazami, których podczas wojennych zawieruch nie ukrywano w skrzyniach zakopywanych w ziemi. Na terenie przeze mnie opisywanym trwały wraz ze świętymi obrazami do końca - najczęściej niszczone przez ogień. „One musiały strzec do końca a jeżeli spalił je ogień, to tak musiało być”. To przekonanie jest powszechne. Sacrum, a tak traktowano również niektóre z ksiagg przechowywanych w wiejskich chatach - musiało trwaniem swoim znaczyć czas do końca, do wypełnienia się niejako zapisów profetycznych. Chroniono przed ogniem ,papiery domowe" - tj. dokumenty własnościowe, testamenty, pokwitowania opłat, paszporty ludzi i koni, metryki etc. Wchodziły one w zasób domowych pamiątek i dokumentów, w których nie brakło również fotografii, listów i okazjonalnych zapisków - tworzyły one swoistą kronikę domu, strzegły prawa do ziemi, potwierdzały zawarte umowy, były swego rodzaju pamiątkami trwania, radości wspólnoty, utrwalonej przez przygodnego fotografa w przypadku fotografii, bólu codziennego, szpargałów a wśród nich listów, które choć ozdobione pierzastymi łabędziami i aniołkami, nie zbudowały rodzinnego gniazda ale pozostały synonimem młodości i pamiątkami minionego czasu.

„W pierwszym etapie w połowie XIX wieku można przypisać tandetnym wydawnictwom wyraźne zasługi. W wielu wypadkach były one pierwszą lekturą docierającą do ludowego czytelnika, dostosowaną do jego poziomu i zainteresowań: tzw. książka ludowa potrafiła lepiej niż dydaktyczne dziełka przełamywać obojętność wobec słowa drukowanego, wdrażać do nawyku czytania. Szczególne znaczenie miały polskie wydawnictwa popularne na terenach zagrożonych wynarodowieniem (...), gdzie był często jedynym polskim słowem drukowanym". ${ }^{17} \mathrm{Z}$ relacji wynika, że oprócz modlitewników i druków zaliczanych do literatury tandetnej, rzadko wspomina się tekst biblijny. W domowych bibliotekach był on rzadkością. Szczególnie tekst Starego Testamentu zapewne wielokrotnie napotykał na niezrozumienie. Sta- 
nisława Grom z Folwark Małych interpretuje małe zainteresowanie tekstem biblijnym: „(..) i wyrazy były trudne, i historie opisywane były jakieś obce. Były przecież pieśni o tym jak Matka Boska obok nas przechodziła uciekając do Egiptu, odcisnęła stopę w Knorydach w kamieniu i w Dolistowie. Ludzie leczyli najprzeróżniejsze dolegliwości zbierając ze stopek wodę. Wolałam też kantyczki, byli w nich nasi sąsiedzi, pastuszkowie, był też Żyd z Zabłudowa - Jankiel, to chyba o niego chodziło, było w tych tekstach bardziej po naszemu. W kościele ksiądz odczytywał Pismo Święte i nam je thumaczył. Więcej nauk było chyba w, „Żywotach Świętych”. W naszym domu nie było Biblii ale ludzie dużo o niej opowiadali, szczególnie o Chrystusie i Matce Boskiej. Sama już nie wiem czy te opowieści były brane z Biblii?”

Ze wstępnej analizy wynika, że w tzw. zakładzinach chłopskich bibliotek prym wiodły druki kramarskie, zaliczane do literatury ludowej. Wydawcy znakomicie znali zapotrzebowanie społeczne odbiorców na wsi. Rzadkie wędrowanie do odległych miejsc kultu, skąd zapewne przywożone były książki, potwierdzały i niejako dokumentowały "niecodzienne historie" gdzieś zasłyszane. Były pamiątkami z miejsc odpustowych i utrwalały tym samym zasłyszane zdarzenia z homiletyki ludowej, która korzystała z przekładów literatury ludowej. ${ }^{18}$

Do nielicznych źródeł pamiętnikarskich z gminy Zabłudów należą dwie książki Stanisława Dakowicza, ur. w 1898 r., rolnika ze wsi Krynickie. We „Wspomnieniach” pisal: „Pewnej niedzieli po przyjeździe z kościoła, wyjmuje ojciec z kieszeni złożony papier i daje mówiąc do mnie: masz Stachu to dla ciebie. Rozwijam, patrzę i widzę, że coś napisano, ale nic nie rozumiem. Wtedy ojciec mi wyjaśnił, że to jest abecadło duże i małe ale pisane w takiej samej kolejności jak drukowane. Były tam również cyfry od 1-30 i wreszcie trzy wiersze odręcznego pisma: $<$ Bóg pomocą temu bywa, kto Go na ratunek wzywa $>,<$ Bez pracy nie będzie kołaczy / chleba $>, \mathrm{i}<$ Ludzie pracujący podobni mrówkom $>$. Na prośbę ojca abecadło to, cyfry i tych pare wierszy napisał mi miejscowy organista. Ojca stryjeczny brat, Józef Dakowicz z Halickich, służył wówczas w wojsku rosyjskim w randze wachmistrza w Białymstoku. On to później dostarczył mi różnych książek i pism potrzebnych do nauki. Tak więc mając dwanaście lat w nauce przewyższałem mych kolegów, uczęszczających do szkoły rosyjskiej, bo oni uczyli się wyłącznie po rosyjsku, ja zaś uczyłem się jednocześnie po polsku i po rosyjsku. Umiałem już biegle czytać, pisać, znałem działania arytmetyczne z ułamkami. Jak na owe czasy i na mój młodociany wiek, był to stan mojej wiedzy zadawalający. Warunki w jakich się znajdowałem, 
były bardzo niepomyślne, a nawet ciężkie, z powodu (...) kapryśnej i złośliwej macochy". ${ }^{19}$

W „Kronice wsi Krynickie” tenże autor odnotował: „Nastawienie władz rosyjskich w stosunku do Krynickich było wrogie, a to $\mathrm{z}$ tego powodu, że Krynickie nie zgodzili się na pobudowanie we wsi szkoły, tak zwanej $<$ Narodnoje Uczyliszcze>, którą rząd carski chciał wybudować własnym kosztem. Krynickie w obawie rusyfikacji, woleli znosić szykany i prześladowania. Pragnąc zachować swoją ojcowską mowę i obyczaje, uczyli swe dzieci po polsku potajemnie $w<$ szkole ruchomej>. (codziennie zmieniano lokal szkolny a lokalem tym były mieszkania prywatne), utrzymując własnym kosztem nauczyciela". ${ }^{20}$

Mając na uwadze rolę chłopskiego domu w realiach końca XIX wieku jako instytucji społecznej, a opisując funkcję książki w kulturze narodowej, nie sposób pominać zachowane źródła pamiętnikarskie. Są nieliczne ale i one wyraźnie wskazują na trudne i sporadyczne zainteresowanie książką w tym środowisku. Istniały biblioteki domowe w środowisku wiejskim, w dworach, na plebaniach, w domach nauczycieli. Należy domniemywać, iż były one wykorzystywane w edukacji chłopskiej i stawały się przy tym wzorcem do budowania własnych księgozbiorów, chociażby w sferze trudnych do zrealizowania marzeń. I były one gromadzone przypadkowo. ${ }^{21}$ Nieco światła rzucają pamiętniki chłopów na ówczesne warunki edukacyjne i zainteresowania książką. Nie są one jedynie opisem trudnego dzieciństwa i ,startu w życie”. Wskazują przede wszystkim na olbrzymie zapóźnienia wynikające $z$ dramatycznej sytuacji politycznej, dojmującego ubóstwa i nadrabiania wielowiekowych zaniedbań edukacyjnych. Anonimowy gospodarz średniorolny z województwa białostockiego w pamiętniku ukończonym w 1933 roku pisał m.in. „Na pierwszej lekcji nauczyciel rozdał nam elementarze rosyjskie, za które kazał nam przynieść zapłatę, a także kazał, aby każdy uczeń zaopatrzył się w łupkową tabliczkę i rysik, a potem objaśnił nam, że nauka odbywać się będzie w języku rosyjskim i że tylko po rosyjsku mamy rozmawiać pomiędzy sobą i zwracać się do nauczyciela. (...) Moja umiejętność czytania tak podziałała na sąsiadów, że postanowili powierzyć mi nauczanie swych dzieci i powstała we wsi szkoła. Postarano się o deski, zrobiono duży, długi stół na sztalugach, a wkoło niego ławy. Wybrano na szkołę największą izbę we wsi i nauka się rozpoczęła. Miałem wtedy lat jedenaście".22

W okresie międzywojennym - jak podkreślają moi rozmówcy -pojawiają się na Zabłudowskiej Ziemi pierwsze rękopiśmienne zeszyty wypełnione 
wierszami, piosenkami, rymowankami sztambuchowymi, wzorami dedykacji umieszczanych na fotografiach, tekstami powinszowań okolicznościowych, ,wiankami weselnymi” czyli oracjami wierszowanymi recylowanymi podczas zaślubin i wesela itp. w domowych biblioteczkach. Oddzielne zeszyty poświęcone były pieśniom majowym i modlitwom - zastępowały one dotkliwy brak książek i śpiewników, tak jak chociażby zeszyty z pieśniami pogrzebowymi. Te swoiste antologie rękopiśmienne, zdobione często okolicznościowymi rysunkami, pełne przy tym kaligraficznych prób - stają się wewnętrzną potrzebą ocalenia coraz bogatszej literatury towarzyszącej człowiekowi w jego codziennym życiu. Pamięć, która przechowywała pieśni, bajki, opowieści osadzane w najbliższym pejzażu, oprócz wspomnianych pieśni, nie skodyfikowanych a otwartych na ciągłe dopowiedzenia. Teksty skodyfikowane zaś, wymagające wspólnego wykonywania, nie mogły być prezentowane w postaci najprzeróżniejszych wariantów (powszechne: „oni przyjechali z innej okolicy i robią to po swojemu, nie możemy z nimi razem śpiewać, inne u nich słowa i nuta też się różni"). Stąd potrzeba zapisywania i posiadania „utrwalonego w piśmie” przekazu ustnego, bądź wiernego kopiowania pieśni z najprzeróżniejszych źródeł, które zazwyczaj nie ulegały jakimkolwiek zmianom i dowolnym transkrypcjom. Wyjątek stanowią pieśni o rodowodzie staropolskim, które wykonywane współcześnie a zapisane onegdaj w zeszytach, które podlegały kolejnym przepisywaniom - niezrozumiałe już dzisiaj wyrażenia próbowały korygować, nadając im niekiedy niezamierzenie humorystyczny charakter, stając się przez to pieśniami niezrozumiałymi. Wystarczy przytoczyć współcześnie wykonywane przez wiernych pieśni. Zamienione w kolędzie słowa „i Józef stary” na ,i Józef święty" - tę zmianę przyjmują moi rozmówcy ze zrozumieniem a niektórzy z nich zgodnie potwierdzają, że w swoim dzieciństwie nie rozumiały tegoż wersu i zapewne indoktrynowane w szkole $w$ latach pięćdziesiątych śpiewały: ,i Józef Stalin”. Przytaczam też przykład z pieśni maryjnej w której wers: „weź w porękę Maryjo” wykonywany jest jako ,weź pod rękę Maryjo" wywołuje wśród wykonawców zakłopotanie. Przykładów można przytoczyć wiele. Zmiany zachodzące w języku i naturalny proces uwspółcześniania tegoż języka wymagałby szczegółowych badań językowych i kulturowych. Kuria Arcybiskupia w Białymstoku wydała w 1984 roku „Pogrzebowe pieśni ludowe” zebrane i ułożone - jak zapisano na karcie tytułowej - przez „,ks. Stanisława Fiedorczuka do użytku wewnętrznego" - książka ta wypełniła dotkliwą lukę w ujednolicaniu dotychczasowego repertuaru pieśni pogrzebowych, odchodzenia od dowolności wprowa- 
dzania do zbiorów rękopiśmiennych nie odpowiadających „majestatowi śmierci" i teologicznym prawdom wiary zanurzonym w rozpaczy i beznadziei dalekich od „wiary w zmartwychwstanie”. Jak wielką popularnością cieszyła się wspomniana publikacja, niechaj zaświadcza fakt, iż w kilku wsiach w parafii zabłudowskiej, naliczono kilkanaście egzemplarzy. ${ }^{23}$ Od kilku lat ogromną popularnością cieszą się książki wydawane przez Wydawnictwo Duszpasterskie Rolników z Włocławka, rozprowadzane przez parafię, które mogą liczyć na cenne upominki za propagowanie tychże wydawnictw. Włocławska oficyna weszła brawurowo na ten rynek, wydając w 1992 roku po raz pierwszy „Kalendarz rolników” pełen informacji historycznych, zaleceń gospodarczych, porad zielarskich, poezji ludowej, opowiastek, informacji o kościele w Polsce, pszczelarstwu, żywieniu (np. jak zapobiegać poprzez odpowiedni styl życia chorobom na tle wadliwego żywienia i uzależnienia od tytoniu, przez żołądek do serca, znaczenie naturalnego odtruwania) i humoru. Z roku na rok wzrastają nakłady kalendarzowe a książi tegoż wydawnictwa zasilają biblioteczki domowe we wsiach należących do gminy i parafii zabłudowskiej, sq to wydawnictwa o atrakcyjnej cenie i przy znakomicie zorganizowanym kolportaźu (wybór pozycji proponowanych przez parafię jest wyraźnie określony, nie trafiają tu pozycje książkowe, które mogłyby budzić jakiekolwiek wątpliwości, zazwyczaj związane z Kościołem i pracą duszpasterską szeroko pojmowaną). Coraz więcej w wiejskich biblioteczkach domowych napotkać można publikacji książkowych adresowanych do rodziców jak chociażby: „Kocham Cię Mamo" - ,jest to książka zawierająca ponad 120 wierszy i wierszyków poświęconych naszym mamom, aby wśród szarej codzienności życia mocniej podkreślić, że je kochamy. Zebrane tu wiersze przydatne są na takie uroczystości jak: imieniny, urodziny, rocznice ślubu i inne okazje. Książka zawiera wiersze łatwe - dla dzieci najmłodszych, i trudniejsze - dla dzieci starszych i młodzieży. Zbiorek ten, to książka bardzo przydatna dla wychowawców, a więc katechetów, nauczycieli, rodziców i stanowi doskonałą pomoc w wychowaniu dla szacunku, czci i miłości względem rodziców, a zwłaszcza mamy” - z noty wydawniczej „Kocham Cię, Babciu”, „Kocham Cię, księże”, „,Kocham Cię, Ojcze Święty”, „Kocham Cię, nasza pani”, „Kocham Cię, Święty Mikołaju" i dodajmy wydawnictwa adresujące swoje książki do rolników proponują m.in. „Jasełka i scenki na Boże Narodzenie” w dwóch tomach, każdy z nich w cenie $5 \mathrm{zł}$; kazania patriotyczne i dożynkowe, jak chociażby „Ziemia jest rzetelna” ks. bp Romana Andrzejewskiego w której, jak wynika z noty redakcyjnej: (...) „Autor apeluje o ochronę śro- 
dowiska naturalnego i utrzymanie ziemi jako przestrzeni danej przez Boga do życia człowieka, wskazując na problemy związane z polityką rolna, szczególnie z opłacalnością produkcji żywności, postuluje łączenie się rolników w grupy zawodowe i zorganizowane działania gospodarcze i społeczne" i tegoż autora „Rzetelne są ręce rolników” - „w książce są zebrane homilie i przemówienia wygłoszone do rolników przy różnych okazjach, jak np. pielgrzymki sołtysów do Lichenia i różnych grup rolników do innych sanktuariów w Polsce". Przytaczam fragmenty not wydawniczych, wszak one wyraźnie wskazują na palącą niejako potrzebę wypełniania luk informacyjnych, które powstają w środowisku wiejskim w procesie transformacyjnym, dotkliwie odczuwanych przez wieś. Książki o których wspominam, znajdują się w kilkunastu domach na terenie poddawanym analizie. Z informacji udzielonych przez miejscowego ks. proboszcza - Józefa Krysiewicza wynika, że „każdy tytuł sprowadzony z tegoż wydawnictwa znalazł nabywców". Nie znamy ile egzemplarzy trafiło na ten teren zamawianych wprost u wydawcy, wszak w każdym, rokrocznie wydawanym kalendarzu, pojawia się kolejna oferta. Można domniemywać, że liczba ta jest znacznie wyższa. ${ }^{24}$ Tym bardziej, że propozycje tegoż wydawnictwa wypełniają dotkliwą lukę proponując m.in. „Pieśni nabożne” - jak pisze wydawca w nocie wydawniczej: „W wielu regionach naszej Ojczyzny zachowal się jeszcze piękny zwyczaj gromadzenia się na modlitwie przy trumnie na tzw. pustych nocach, tuż przed pogrzebem zmarłego. Rodzina, przyjaciele, sąsiedzi, znajomi poprzez modlitwę śpiewaną polecają Bożemu Miłosierdziu zmarłą osobę. (...) Książka drukowana jest dużą, ułatwiającą korzystanie $z$ niej, także przez osoby starsze czy z osłabionym wzrokiem, czcionką. Książka doskonale zastępuje i uzupełnia stare, nadgryzione zębem czasu, od lat ręcznie przepisywane, zbiorki z podobnymi pieśniami" - podkr. J.L. Ponadto przez to wydawnictwo wydawane są poradniki typu: Zbigniewa Przybylaka: „Słynne leki ziołowej apteki”, „Słynne leki antyrakowe”, „Słynne leki domowej apteki”, czy „Jak przepowiadać pogodę”, Ewy Aszkiewicz: „Ciasto drożdżowe” (przy zalewie rynku księgarskiego wydawnictwami propagującymi kuchnie krajów egzotycznych i wymyślnych potraw - pojawia się potrzeba wydawania przepisów najprostszych, najtańszych i produktów łatwych do zdobycia). Książki te stanowią znaczny procent w bibliotekach domowych penetrowanych przeze mnie. Oferty innych wydawnictw związanych z Kościołem Rzymskokatolickim trafiają w śladowych ilościach, oprócz Wydawnictwa OO. Franciszkanów z Niepokalanowa - decyduje cena wydawnictw i jak już wspomniałem przystępny 
język oraz atrakcyjność wznowień, chociażby w postaci kolejnych wydań kantyczek, ${ }^{25}$ wydawnictwa OO. Jezuitów należą już do sporadycznie sprowadzanych na teren parafii z wyjątkiem modlitewników wydawanych przez Prowincję Małopolską i wznowionego po przerwie „peeselowskiej” „Posłańca Serca Jezusowego". Sporo tytułów trafia na poddany przeze mnie teren obserwacji - z Wydawnictwa OO. Marianów (wynika to z „drożności” pielgrzymich szlaków prowadzących z Zabłudowa do sanktuariów Lichenia i Gietrzwałdu).

Nie ma też w systemie parafialnej promocji zbyt wielkiego zainteresowania wydawnictwami Kurii Metropolitalnej w Białymstoku. Oprócz wspomnianych „Pieśni pogrzebowych” ks. Stanisława Fiedorczuka -wydawnictwa są adresowane głównie do księży i katechetów i hermetyczność języka nie pozwala im wejść do domowych, wiejskich biblioteczek. Jedynie miesięcznik „Czas Miłosierdzia" dociera do czytelników kupowany jak mi oświadczyła jedna z parafianek: „kupuję bardziej z przyzwyczajenia i szkoda mi ministrantów stojących przed kościołem na zimnie i w deszczu, to kupuję, żeby już nie czekali na kupca".

Pomimo wyraźnie dającego się zauważyć dalszego procesu ubożenia środowiska wiejskiego „masowość procesu dotyczy jednak głównie treści łatwych w odbiorze, dla których rozumienia wystarczy nawet wykształcenie niepełne podstawowe" - pisze Anna Pawełczyńska analizując czytelnictwo na wsi, dodaje: „Analiza zespołu zachowań kulturowych, których element stanowi czytelnictwo, prowadzi ponadto do wniosku, że zainteresowanie literaturą piękną towarzyszy innym zainteresowaniom czytelniczym. Czytelnik literatury pięknej, to równocześnie czytelnik książek kształcących w zawodzie i czytelnik prasy codziennej. Mamy zatem do czynienia z zespołem współwystepujących zachowań czytelniczych, które są ściśle związane z zainteresowaniem przekazania kultury masowej. Kształtuje się wyraźnie pewien wzór kulturowy, w którym każda forma uczestniczenia we współczesnej kulturze zwiększa szansę uczestniczenia w innych formach kultury" ${ }^{26}$ Stwierdzenie powyższe osadzone w realiach Polski Ludowej wymaga postawienia dodatkowych pytań, wszak ogólnikowa analiza potwierdza, iż procesy czytelnicze związane są z oddziaływaniem miedzy innymi mass-mediów i potrzeb wynikających z najprzeróżniejszych form kształcenia - ogranicza się coraz wyraźniej do kultury masowej, tracąc kontakt z książką na rzecz informacji obrazkowej. Następuje zauważalny w ostatnim okresie proces porzucania „lektur nakazanych czy polecanych" na rzecz wolnego wyboru, dalekiego często od zakładanych form 
kształcenia na rzecz kultury wysokiej. W środowiskach wiejskich następuje wyraźny etap nawiązujący do przerwanych procesów naturalnego kształtowania gustów i potrzeb czytelniczych. Literatura, jak już wspomniałem wcześniej, według opinii środowiska wiejskiego „winna uczyć a nie marnotrawić i na manowce prowadzić, rynsztokowymi karmić treściami, być użyteczną bo od innych książek człowiek tylko ghupieje, rodziców nie poznaje, pysznym się staje i ku potępieniu zmierza". ${ }^{27}$

Badaniami i opisem objęto biblioteczki domowe we wsiach: Zwierki, Protasy, Łubniki, Folwarki Małe, Rafałówka, Krynickie, Halickie i Zajezierce. Informacje zebrano od Genowefy Ostaszewskiej i Reginy Buraczyk (Zwierki), Jana Horodeńskiego (Protasy), Stanisławy Michałowskiej i Marii Leończuk (Lubniki), Stanisławy Grom (Folwarki Małe), Róży Nosorowskiej (Rafałówka), Marianny Borowskiej (Krynickie), Józefy Dakowicz (Halickie) i Stanisławy Minko (Zajezierce). Biblioteczki, tak nazywali moi rozmówcy swój niewielki księgozbiór, liczący od kilkunastu do kilkudziesięciu książek, wśród których nie brakowało również starych podręczników szkolnych, pamiętników (album amicorum), zeszytów z pieśniami nabożnymi, wszelkiego rodzaju druczków dewocyjnych, zszywek prasy katolickiej, głównie „Posłańca Serca Jezusowego” i „Rycerza Niepokalanej”, starych kalendarzy rolniczych, poradników wydawanych przez Ośrodki Doradztwa Rolniczego, zbiorów pocztówek, albumów z fotografiami, listów, wszelkiego rodzaju dokumentów i szpargałów. Na pytanie moje skierowane czy jest sens przechowywania owych szpargałów, moi rozmówcy w większości potwierdzali, że są to ,pamiątki i nie przeszkadzają miejsca dużo a ludzie mają więcej książek i papierów i wcale to im nie zawadza" (S. Grom), zaś Regina Buraczyk (Zwierki) wypowiedziała to wprost: „Od czegoś trzeba zacząć, nie ma u mnie pięknych książek ale są potrzebne, są książki do nabożeństwa mojej babci, z posagiem mojej mamy weszła do naszego domu w Józefowie książka o świętych, ich żywoty, opisy męczeństwa i modlitwa do nich kierowana. Kiedyś otrzymałam od wujka książkę o Heli co strzegła polskich granic, moja matka chrzestna też mi podarowała książkę. Te książki są w moim domu i tworzą biblioteczkę pamiątek, do których z wiekiem coraz częściej powracam". A Jan Horodeński (Protasy) określił to następująco: „Nie we wszystkich domach były książki, w naszym już przed wojną były, głównie literatura religijna. Brat mojego ojca został księdzem, pracował w Kobryniu, potem wywieźli go do Workuty, był skazany na karę śmierci a książki z czasów jego nauki były jak relikwie. Babcia moja czekała, że dojrzy go jeszcze w swoim życiu, a on powrócił 
z sowieckiego raju w 1959, w rok po śmierci swojej matki. W naszym domu była biblioteczka księdza, którą doglądała moja babcia i nasza biblioteczka - mojej mamy, przechowywana w kufrze, potem w szafie, dzisiaj książki z niej, mniej sfatygowane leżą za szkłem w regale, a te ze zniszczonymi okładkami w kufrze na strychu. Dzisiaj rzadko z tych książek korzystamy, częściej przed telewizorem, wystarczy pilotem zmienić kanały i nie trzeba ślepić się nad drukiem. A dawniej, w zimowe wieczory siadała przy lampie moja mama, a my w ciepłym łóżku i w półmroku słuchaliśmy wyczytanych z książek historii”. Stanisława Minko (Zajezierce) na moje pytanie jakie książki były w jej domowej bibliotece odpowiedziała: „Nie wiem czy była to biblioteka, bo książki można było chyba policzyć na palcach rąk. Ale te książki stanowiły dla nas wiedzę jakby o całym świecie, przekraczały nasze horyzonty. Pieczołowicie przechowywane, część z nich była dobywana z kufrów przy szczególnych okazjach. Tata mój nazywał mebel stojący w największej izbie: kufrem bibliotecznym. Były w nim najprzeróżniejsze papiery, oprócz książek przechowywano w nim akty własności, paszporty, stare fotografie, w nim zawieruszył się mój zeszyt szkolny. Chodziłam wtedy do szkoły w Kamionce i narysowałam piękny bukiecik kwiatów. Mamie to chyba bardzo się spodobało, bo ten zeszyt trafił do kufra. Pokazuję to moje szkolne świadectwo moim wnukom. Na co dzień moja babcia modliła się z książek, znała pismo. Kiedyś pamiętani nasz stary dom i książki (były chyba dwie lub trzy) spoczywały na tremie, po pożarze nowe już książki mama wkładała do szuflady stołu w tzw. wielkiej chacie, to znaczy izbie, która zawsze wysprzątana, często nieopalana, czekała na szczególnych gości albo wyjątkowej wagi uroczystości - takie jak chrzciny, wesela i pogrzeby. Wtedy książka, pewnie dlatego, że była rzadkim gościem w chłopskiej chacie - otoczona była nimbem świętości chyba dlatego, że była to książka religijna. Z niej poznałam pierwsze litery, zanim trafiłam do szkoły". Przytaczam jeszcze fragment relacji Stanisławy Michałowskiej z Lubnik „były u nas, to pamiętam jeszcze z dzieciństwa, książki. Były chyba dwie i jak pamiętam były to modlitewniki. Babcia nie umiała czytać ale prosiła nas kiedy już nie mogła się poruszać, żeby jej zdjąć z tramy książki z modlitwami. Przewracała kartki i szeptała swoje modlitwy. Moja mama umiała już czytać, nauczył ją Joksz, mieszkał za wsią. Przynosił do nas „Sybillę" i czytał proroctwa. Stuchaliśmy wtedy z wielkim zaciekawieniem, nie rozumiałam, że smoki będą latać po niebie. Potem mama kupiła gdzieś sennik. W niedzielę, po odśpiewanych godzinkach, odgadywała sny z całego tygodnia. Przychodzili inni, im też thumaczyła co może się zdarzyć. W tych kil- 
ku książkach, jak zakładki, wkładane były święte obrazki. One mi najbardziej się podobały, były kolorowe. Mieszkał też u nas Andrzej, nazywali go świętym, z rzadka się z innymi ludźmi kontaktował, zbierał tylko jak już był stary, fotografie. Spłonął ze swoim domem na Boże Narodzenie. Z pogorzeliska wydobyto bryłę srebra ze spalonych ikon i resztki kufra w którym były książki. Zbieraliśmy te stronice ale one nie były po polsku, chyba po rusku. On przyjechał z Rosji „po bieżeństwie”. Pamiętam, że pokazywał nam książkę, pamiętam nawet jej tytuł: „Nowyj Arakul”, czytał z niej jakieś przepowiednie (...)".

Przytoczone relacje zaledwie odsłaniajązatrzymane w pamięci fragmenty dotyczące ówczesnej produkcji literackiej docierającej „do ludu” i pierwszych inicjacji czytelniczych. ${ }^{28}$

Winienem w tym miejscu użyczyć nieco danych statystycznych dotyczących opisywanych bibliotek. Odstąpię jednak od tego zadania, zważywszy, iż wnioski wypływające $z$ tegoż zestawienia będą błędne i nie wniosą niczego nowego do tematu. Będą przykładowym oglądem dalekim od rzeczywistości, wszak resztki owych bibliotek pozostałe po dramatycznych losach wiejskich domów, rekonstruowane „pamięcią" informatorów, nie stworzą pełnego obrazu.

Pozwalam więc na opis posiłkujący sięjedynie fragmentami dobywanych wspomnień, wszak one są w stanie przywołać „książki-legendy domowe”, które towarzyszyły i były często ,zakładziną" tychże bibliotek.

Coraz częściej w chłopskich księgozbiorach pojawiają się książki związane $\mathrm{z}$ osobami dokształcającymi się $\mathrm{w}$ rodzinie, oprócz podręczników, często zdezaktualizowanych, pojawiają się wydania aktualne. Beletrystyka ograniczana jest również do potrzeb szkolnych, tj. pozycji lekturowych, szczególnie tam, gdzie szkolna biblioteka nie dysponuje dostateczną ilością lektur. Coraz więcej książek przypadkowych znajduje miejsce w domowych biblioteczkach, zakupionych jako pozycje przecenione. Nie zawsze one współgraj ąz zainteresowaniami czytelniczymi ich właścicieli. W większości decyduje atrakcyjna szata graficzna i cena. Kolportaż parafialny ma decydujący wpływ na kształt bibliotek domowych. Przywołuje, gdzieś głęboko tkwiące przez długie lata, sentymenty, które ulegają dzisiaj urealnieniu. Stare, zniszczone książki, wędrują na strych, tworząc na nim składowisko, które warte jest „,archeologii bibliofilskiej”. Książka religijna z ,zaobrazia", tramy i kufra - weszła do biblioteczek domowych. W środowisku wiejskim nie musiała się wstydzić w okresie ,jedynie słusznej ideologii" a wszelkie odstępstwa - pamięć ludzka zachowuje jako naganne. 
Postulowana przez Elżbietę Słodkowską ${ }^{29}$ konieczność opracowania bibliografii księgoznawczej - pozostaje nadal w sferze marzeń. Biblioteki domowe z rzadka, jako temat naukowych rozważań, pojawiają w piśmiennictwie naukowym. Nieliczne prace dotyczące głównie księgozbiorów magnackich, dworskich, kościelnych czy nauczycieli wiejskich, nie przełamują milczenia nad tą problematyka. ${ }^{30}$

Zarysowując zaledwie problematykę chłopskich bibliotek domowych i ich recepcji - powtórzyć opinię za Elżbietą Słodkowską badającą biblioteki prywatne: „Historyka książki dziewiętnastowiecznej nazwa „biblioteka domowa" powinna budzić przede wszystkim zakłopotanie. W trakcie poszukiwań materiałów do niniejszego artykułu natrafiono zaledwie na jedną pracę, która dotknęła problemu biblioteki domowej i jej funkcji w życiu ludzkim. Jest nią felieton Melchiora Wańkowicza pt. „Biblioteki domowe” zaczynający się od słów: „Biblioteka prywatna... samo słowo budzi we mnie ciepłe wzruszenie. I samo słowo budzi we mnie zgryzotę niepewności". ${ }^{11}$ W historyku książki dziewiętnastowiecznej nazwa „biblioteka domowa” powinna budzić przede wszystkim zgryzotę niepewności z powodu braku informacji bibliograficznych na ten temat i trudności metodycznych", ${ }^{32}$

Oprócz wspomnień, chłopskich pamiętników i literackich resentymentów o chłopskich bibliotekach domowych - nie odnalazłem żadnej, związanej z tym tematem literatury naukowej.

Niechaj mi będzie wybaczona odwaga zasygnalizowania jedynie tego tematu - w mojej „najmniejszej ojczyźnie - Zabłudowskiej Ziemi”.

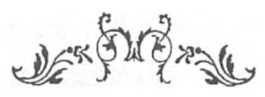

Przypisy:

'Karol Głombiowski: Ksiqżki w procesie komunikacji spolecznej. Wrocław 1980, s. 13.

${ }^{2}$ Maria Kocójowa: W poszukiwaniu modelu badań. W: Roczniki Biblioteczne R. XXVII: 1983, z. 1-2, s. 383-385.

${ }^{3}$ Zob. Kazimiera Maleczyńska: Polski repertuar wydawniczy doby zaborów (problematyka i glówne tendencje rozwojowe). W: Roczniki Biblioteczne R. XXVII: 1983, z. 1-2; s. 284-286.

"Por. Marian J. Lech: Biblioteki „Iudowe” w Królestwie Polskim 1897-1906. W: Studia o Ksiqżce. T. 3, Wrocław 1972.

${ }^{5}$ Janusz Dunin: Uźródel czytelnictwa ludowego. W: W'́wiecie pieśni i bajki. Studia folklorystyczne. Wrocław 1969, s. 93 i in. Janusz Dunin: Pismo zmienia świat. Czytanie Lektura Czytelnictwo. Warszawa - Łódź 1998. 
${ }^{6}$ Ksiażka do nabożeństwa dla wszystkich katolików z polecenia najprzelebniejszego Arcybiskupa Dunina ulożona (...) Dla Kobiet. Częstochowa 1883.

${ }^{7}$ Józefa Dakowicz, ur. 1910, not. Halicki (1973).

' Janusz Dunin: Papierowy bandyta. Ksiażka kramarska i brukowa w Polsce. Lódź 1974. zob. Czesław Hernas: Potrzeby i metody badania literatury brukowej. W: O wspólczesnej kulturze literackiej. Red. S.Źólkiewski i M. Hopfinger. Wrocław 1973. zob. Slownik literatury populamej, pod red. T. Żabskiego. Wrocław 1997.

${ }^{9}$ Ryszard Waksmund: Literatura dla ludu. W: Slownik literatury popularnej pod red. T. Żabskiego. Wrocław 1997, s. 205-206.

${ }^{10}$ Ludwik Brożek: Slownik Folkloru Polskiego. Warszawa 1965.

"Grażyna Zakrzewska-Dąb: Zabludów w XLX wieku (maszynopis); dane zaczerpnięte ze Slownika Geograficznego Królestwa Polskiego i innych krajów slowiańskich t. XIV, Warszawa 1895, s. 191.

${ }^{12} \mathrm{~J}$. Łukaszewicz. Bialystok w XLX wieku. Studia i materialy do dziejów miasta Bialegostoku. T. III, Białystok 1972, s. 59, P.Bobrowski. Grodzieńskaja Gubemia cz. 1l, Petersburg 1863, s. 476-477.

${ }^{13}$ Dane zostały uzyskane dzięki uprzejmości burmistrza Urzędu Miasta i Gminy Zabłudów Mieczysława Ładnego.

${ }^{14}$ Informacja Józefa Dakowicz, ur. 1910, Halickie, zapis z 1980 r.

${ }^{15}$ Mądra rozmowa Królowej ze Sabby z królem Salomonem okolo roku 875 przed narodzeniem Chrystusa Pana. Warszawa 1910 r.

${ }^{16}$ Informacja Józefa Dakowicz, ur. 1910, Halickie, zapis z 1980 r.

${ }^{17}$ Janusz Dunin, op. cit., s. 290

${ }^{18}$ „Kazania po wsiach są zwykle naukami praktycznemi: głównąich zaletą bywa: odpowiedni temat, jasny, przestępne wyłoęnie, język prosty, ale czysty, porównania i przykłady trafiające do przekonania i zrozumienia ludu wiejskiego. Unikać należy: porównań, czy wyrażeń ordynarnych, trywialnych, stylu i mowy ludowej, zaniedbanej, gdyż to licuje z powagą mówcy kościelnego". Podręczna encyklopedya kościelna, t. XXI-XXIl., Warszawa 1910 , s. 55-56.

${ }^{19}$ Stanisław Dakowicz: Wspomnienia, w opracowaniu J. Leończuka. Zabłudów 1995, S. 11

${ }^{20}$ Stanisław Dakowicz: Kronika wsi Krynickie, w opracowaniu J.Leończuka i J. Szumskiego. Zabłudów 1995, s. 42

${ }^{21}$ Elżbieta Słodkowska: Ksiegozbiory domowe w pierwszej polowie XLX wieku. W: $Z \mathrm{Ba}$ dań Nad Polskimi Księgozbiorami Historycznymi. Szkice i materiały. Warszawa 1981, s. 5-17.

${ }^{22}$ Pamiętniki chłopów. Seria Druga, Warszawa 1936, s. 454, 459; zob. Józef Chalasiński: Mlode pokolenie chlopów, t. I-4, Warszawa 1984.

${ }^{23}$ Dokonano próby rejestracji we wsiach Protasy, Zwierki i Łubniki, gdzie w dwóch ostatnich ludność prawosławna - stanowiąca 50\% mieszkańców - nie korzysta ze wspomnianego zbioru, posługuje się tekstami rękopiśmiennymi i „Bohohłaśnikami” wydanymi w okresie międzywojennym i wznowionymi w latach osiemdziesiątych XX wieku. Próby liczenia dokonano podczas „śpiewów wykonywanych przy zmarłym" w przeddzień pogrzebu.

${ }^{24} \mathrm{~W}$ ofercie jak $\mathrm{i} w$ zbiorach domowych odnajduję książki z tegoż wydawnictwa, pozwolę wymienić kilka tytułów z bogatej oferty, żeby wskazać na potrzeby jakie dają o sobie znać w tym środowisku: Kocham Cię, wiosko moja, Kocham Cię, ziemio rodzinna, Ko- 
cham Cie, Ojczyzno, Kocham Cie, przyrodo nasza, Kocham Cię, chlebie nasz powszedni itp. Osobnym problemem jest tzw. atrakcyjność tytułów w przypadku omawianego wydawnictwa wyraźnie daje o sobie znać prostota, często zdawać by się mogło - natrętna powtarzalność, zamiast wyszukiwania ,atrakcyjnych i chwytliwych" tytułów. Aspekt dydaktyczny, nie ukrywany wstydliwie, odnosi sukces wbrew prognozom wydawniczym i wymaga dodatkowych badań.

${ }^{25}$ Nadal cieszy się niesłabnącą populamością na terenie gminy Zabłudów miesięcznik Rycerz Niepokalanej. W parafii zabłudowskiej odnotowano w 1999 r. 136 prenumeratorów, zważywszy, że rozprowadzany przez laty miesięcznik Osserwatore Romano przy nikłym zainteresowaniu nie jest sprowadzany wraz z kilkoma innymi tytułami prasowymi. Nie są również sprowadzane wydawnictwa albumowe poświęcone wizytom Ojca Świętego Jana Pawła II z powodu wysokiej ceny tychże wydawnictw a co z rym się wiąże - brakiem odbiorców.

${ }^{26}$ Anna Pawełczyńska: Studia nad czytelnictwem. Warszawa 1969, s. 63.

${ }^{27}$ Jan Horodeński, wieś Protasy, ur. $1930 \mathrm{r}$.

${ }^{28}$ Wyczerpująco na ten temat piszą: Janusz Dunin: Papierowy bandyta. Ksiqżka kramarska i brukowa w Polsce, Łódź 1974; Karnawał Dziadowski. Pieśni wędrownych śpiewaków, red. Stanisław Nyrkowski, Warszawa 1973; Jan Wróblewski: Polskie biblioteki ludowe w zaborze pruskim i na terenie Rzeszy Niemieckiej w latach 1843-1939, Olsztyn 1975.

${ }^{29}$ Ibidem, s. 14-15.

${ }^{30}$ Zob. Edward Różycki: Książka polska i księgozbiory we Lwowie w epoce renesansu $i$ baroku. Wrocław 1985; Barbara Bieńkowska, H. Chamerska: Tysiąc lat ksiażki i bibliotek w Polsce. Wrocław 1992; Andrzej R. Zieliński: Spoleczny zasięg ksiażki w Polsce (raport z badań). Warszawa 1988; Kazimiera Maleczyńska: Zbieracze wiejscy. W: Ksiqżki i biblioteki w Polsce okresu zaborów. Wrocław 1987; Kazimiera Maleczyńska: Zainteresowania czytelnicze mieszczan dolnoślqskich okresu Renesansu. Wrocław 1982; Cecylia i Janusz Duninowie: Philobiblion polski. Wrocław 1983; Irena Borecka: Ksiegozbiory prywatne nauczycieli w malych miastach. Poradnik Bibliotekarza nr 55 z 1988 r.

${ }^{31}$ Literatura 1974, z 11 lipca, s. 809.

${ }^{32}$ Ibidem, s. 15. 